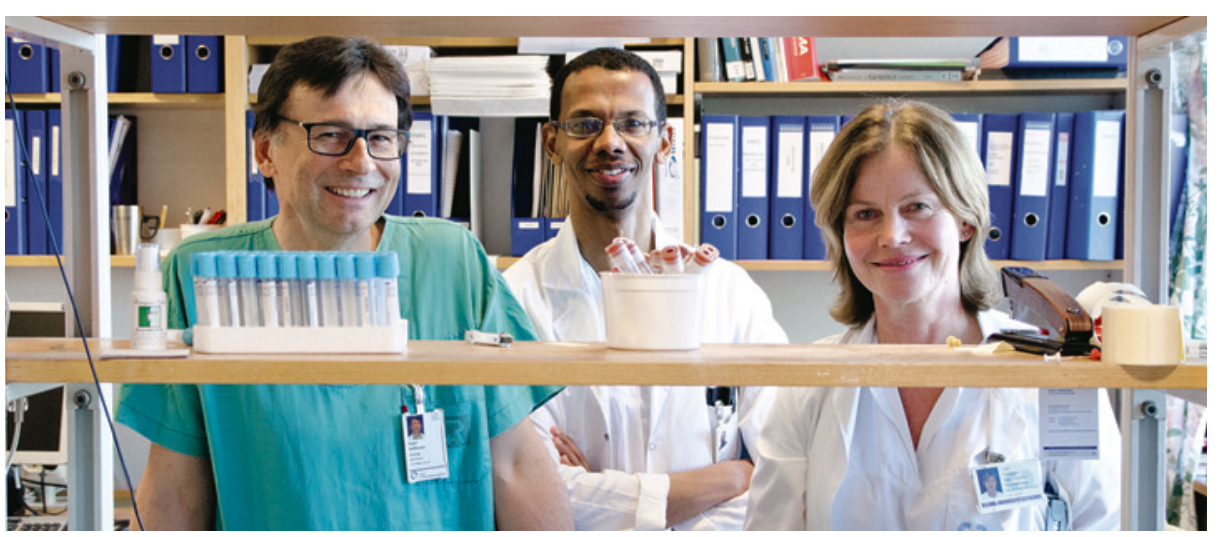

Pavel Hoffman, Fadl Elmula og Aud Høieggen. Foto Ram Gupta, Oslo universitetssykehus

\title{
Justering av legemidler er bedre enn renal denervering
}

\author{
Ved behandlingsresistent hypertensjon er det bedre å justere legemid- \\ delbehandlingen etter hemodynamiske avvik enn å gjøre radiofrekvens- \\ ablasjon av nerveender i nyrene. Dette viser en fersk norsk studie.
}

Hos mange pasienter med høyt blodtrykk vil man ikke oppnå tilfredsstillende behandlingseffekt. De siste årene er radiofrekvensablasjon av nerveender i nyrene, såkalt renal denervering, tatt $\mathrm{i}$ bruk hos slike pasienter, særlig i Mellom-Europa.

Ved Oslo universitetssykehus ønsket man å teste renal denervering i en kontrollert randomisert studie før man eventuelt tok metoden i bruk i vanlig klinisk praksis (1). Pasienter med systolisk kontorblodtrykk over $140 \mathrm{~mm} \mathrm{Hg}$ og systolisk ambulatorisk dagblodtrykk over $135 \mathrm{~mm} \mathrm{Hg}$ ble inkludert i studien etter en grundig utredning. Ambulatorisk blodtrykk ble målt etter bevitnet inntak av morgenmedisinene for å ekskludere pasienter med dårlig medikamentetterlevelse, noe forskningsgruppen tidligere har vist at kan påvirke resultatene (2). Pasientene ble randomisert til renal denervering $(n=9)$ eller justert medikamentell behandling $(\mathrm{n}=10)$ basert på en vurdering av hemodynamiske avvik ved ikke-invasiv integrert hemodynamisk impedanskardiografi.

Studien ble stoppet tidligere enn planlagt fordi man ikke fant effekt av renal denervering utover hva man oppnådde med medikamentell behandling. Etter seks måneder hadde systolisk kontorblodtrykk falt signifikant i medikamentgruppen $(-28 \mathrm{~mm} \mathrm{Hg}$, $\mathrm{p}<0,005)$, men ikke i gruppen som fikk renal denervering $(-8 \mathrm{~mm} \mathrm{Hg}, \mathrm{p}=0,42)$. Systolisk ambulatorisk dagblodtrykk falt med henholdsvis $19 \mathrm{~mm} \mathrm{Hg}(\mathrm{p}<0,005)$ og $10 \mathrm{~mm} \mathrm{Hg}(\mathrm{p}<0,05)$. Ved sammenlikning av gruppene var systolisk kontorblodtrykk signifikant lavere i medikamentgruppen $(\mathrm{p}=0,002)$.
- Denne studien viser at medikamentell blodtrykksbehandling har bedre effekt enn renal denervering hos pasienter med behandlingsresistent hypertensjon når dårlig medikamentetterlevelse og sekundære årsaker er utelukket, sier Aud Høieggen, som er studiens sisteforfatter. - Funnene støtter en avventende holdning til renal denervering og er i samsvar med resultatene fra den nylig publiserte amerikanske multisenterstudien Symplicity HTN-3.

\section{Forskergruppen}

Studien er et resultat av samarbeid mellom forskere og klinikere ved Oslo universitetssykehus og Institutt for klinisk medisin, Universitetet i Oslo. Førsteforfatter Fadl Elmula er overlege og stipendiat ved Avdeling for kardiologi, medisinsk klinikk. Intervensjonsradiolog Pavel Hoffman ved Avdeling for kardiologi, hjerte-, lunge- og karklinikken hadde hovedansvaret for utførelsen av renal denervering. Aud Høieggen, som er førsteamanuensis og overlege ved Nyremedisinsk avdeling, Oslo universitetssykehus, Ullevål, ledet studien, som er finansiert av bl.a. Oslo universitetssykehus.

\section{Kari Tveito}

Tidsskriftet

\section{Litteratur}

1. Fadl Elmula FE, Hoffmann P, Larstorp AC et al. Adjusted drug treatment is superior to renal sympathetic denervation in patients with true treatment-resistant hypertension. Hypertension 2014; 63: $991-9$.

2. Fadl Elmula FE, Hoffmann P. Fossum E et al. Renal sympathetic denervation in patients with treatment-resistant hypertension after witnessed intake of medication before qualifying ambulatory blood pressure. Hypertension 2013; 62: 526-32.
Ordforklaringer

Resistent hypertensjon: Blodtrykk over 140/90 $\mathrm{mm} \mathrm{Hg}$ til tross for behandling med minst tre antihypertensive medikamenter i maksimalt tolerert dose, inkludert et diuretikum.

Renal denervering: Metode basert på hypotesen om at nedsatt aktivitet i afferente og efferente sympatiske nervefibre i nyrearteriene vil kunne senke blodtrykket ved behandlingsresistent hypertensjon. Behandlingen består av radiofrekvensablasjon av nervepunkter i nyrearteriens vegg via et lyskekateter.

Impedanskardiografi: Ikke-invasiv målemetode som tar sikte på å skreddersy antihypertensiv behandling etter underliggende hemodynamiske avvik, slik som å øke dosen av diuretikum hos volumbelastede pasienter eller å behandle med vasodilaterende legemidler hos pasienter med høy perifer motstand.
Artiklene ble publisert i tidsskriftet Hypertension, som er det høyest rangerte tidsskriftet innen blodtrykksbehandling, i juli 2013 og mars 2014. 